\title{
Designing an Educational Effectiveness Model for the Employees of the Selected Organization with a System Dynamics Approach
}

\section{Diseño de un modelo de eficacia educativa para los empleados de la organización seleccionada con enfoque de dinámica de sistemas}

Sedigheh HajiAbedi

Islamic Azad University, Yazd, Iran.

ORCID: https://orcid.org/0000-0003-0064-1804

Hossein Eslami

Islamic Azad University, Yazd, Iran. ORCID: https://orcid.org/0000-0002-0821-1377

SeyedAlireza Afshani

Yazd University, Yazd, Iran.

ORCID: https://orcid.org/0000-0002-2311-3329

Javad Pourkarimi

University of Tehran, Tehran, Iran.

ORCID: https://orcid.org/0000-0001-8986-091X

Received 06-14-20 Revised 08-10-20 Accepted 09-01-20 On line 09-30-20

*Correspondence

Email: h.eslami@iau.ac.ir
Cite as:

HajiAbedi, S., Eslami, H., Afshani, S.A., \& Pourkarimi J. (2020) Designing an Educational Effectiveness Model for the Employees of the Selected Organization with a System Dynamics Approach. Propósitos y Representaciones, 8 (SPE3), e765. Doi: http://dx.doi.org/10.20511/pyr2020.v8nSPE3.765 


\section{Summary}

The purpose of this research is to design an educational effectiveness model for the employees of the selected organization with a system dynamics approach in Iran. In order to achieve the research goal, a sequential mixed method has been used, which includes two qualitative and quantitative parts. In the qualitative part of the research, interview has been used. Necessary information and data were collected from experts and senior managers of the selected organization and then the design of the educational effectiveness model for the employees of the selected organization with a dynamic system approach has been validated. The research results showed that the educational effectiveness model for the employees of selected organization with a system dynamics approach has two parts: the main factors and their indicators. This model has been composed of indicators that are the core and heart of this model and are the basis for evaluating the educational effectiveness, which are called effective factors. The educational effectiveness model for the employees of the selected organization with a system dynamics approach has 7 main factors: learner's readiness, training need assessment, training targeting, training program design, resources and equipment allocation, course monitoring and evaluation and training course management, which includes 56 indicators composing it.

Keywords: Training, Effectiveness, System Dynamics Approach, Employees, Selected Organization.

\section{Resumen}

El propósito de esta investigación es diseñar un modelo de efectividad educativa para los empleados de la organización seleccionada con un enfoque de dinámica de sistemas en Irán. Para lograr el objetivo de la investigación se ha utilizado un método mixto secuencial, que incluye dos partes cualitativas y cuantitativas. En la parte cualitativa de la investigación se ha utilizado la entrevista. Se recopiló la información y los datos necesarios de expertos y altos directivos de la organización seleccionada y luego se validó el diseño del modelo de efectividad educativa para los empleados de la organización seleccionada con un enfoque de sistema dinámico. Los resultados de la investigación mostraron que el modelo de efectividad educativa para los empleados de la organización seleccionada con un enfoque de dinámica de sistemas tiene dos partes: los factores principales y sus indicadores. Este modelo ha estado compuesto por indicadores que son el núcleo y corazón de este modelo y son la base para evaluar la efectividad educativa, los cuales se denominan factores efectivos. El modelo de eficacia educativa para los empleados de la organización seleccionada con un enfoque de dinámica de sistemas tiene 7 factores principales: preparación del alumno, evaluación de las necesidades de formación, focalización de la formación, diseño del programa de formación, asignación de recursos y equipos, seguimiento y evaluación del curso y gestión del curso de formación, que incluye 56 indicadores que lo componen.

Palabras clave: Formación, eficacia, enfoque de dinámica de sistemas, empleados, organización seleccionada.

\section{Introduction}

Improving performance and increasing productivity, in order to achieve maximum output from human and material resources used and optimal achievement of organizational goals, are among the most important duties of managers, which providing effective trainings helps this important issue. In providing effective trainings, there are conditions and factors that affect increasing the performance of managers (Salas, 2013). Organizations have been composed of important pillars such as structure, human resources, technology and management, which according to many experts, human resources are the most important element in this regard, because the efficiency of 
the organization depends on the correct and exact performance of the duties of these forces in the department and headquarter. Since a high percentage of the resources and capitals of organizations are composed of human resources, therefore, providing this human capital requires regular and continuous training activities at all organizational levels (Priyadarshini \& Dave, 2012); in other words, the frequent changes and today's unstable world, having a capable and trained workforce is vital for the growth and success of any organization. Organizations need internal changes to adapt to the environment. In order to implement any kind of change in the organization, management must think about training and informing its employees (Pfeifer et al., 2013).

If in the past holding training courses and the participation of employees in them seemed convincing, today training is expected to be able to facilitate the realization of organizational goals. Therefore, in the education system of organizations, in addition to perform training, the effectiveness of these courses should also be considered (Ford, 2014). Extensive studies indicate how this type of trainings can be designed to achieve goals, however, most of these studies are general and overall in nature and a small number of them have focused specifically on issues. According to the results of some of the researches conducted about specialized courses of the selected organization, despite the high costs spent and comprehensiveness, these courses have not had that much effect on improving employees' performance (Snell \& Bohlander, 2010). Weak content in terms of applicability, not being up-to-date, incompatibility of content with the educational needs of commanders and managers, the lack of attention to the basic topics of teaching the methods of specialized courses, use of traditional teaching methods in training courses, the lack of positive effect of courses on performance have been among the insufficiencies of held specialized courses which shows the necessity of evaluating these courses (Khorasani \& Hasanzadeh Rain, 2007).

In this regard, a training program can only justify its worth when it provides reliable and credible evidences about the effect of training on improving participants' behavioral patterns (Seyed Javadin, 2008). This point refers to an important aspect of education that is usually referred to as "Educational Effectiveness". In other words, the value of education, like other organizational activities, is also measured by determining it in achieving organizational goals (Ghahremani, 2008). Meanwhile, one of the main problems of governmental and industrial organizations and other organizations is the lack of seriousness of employees and managers in education affair, inappropriate evaluation of the educational effectiveness of courses and as a result providing appropriate feedback from training results, and finally when it is necessary, the required follow-up is not performed (Nasreen \& Mirza, 2012).

\section{Literature Review}

(Bani Davoudi \& Atabi, 2018) in a research addressed "The Relationship between the Effectiveness of In-Service Courses of Employees with Job Consequences in Abuzar Hospital in Ahvaz", in the Journal of the Paramedical Faculty of Tehran University of Medical Sciences. This cross-sectional research was of descriptive-analytical type and in terms of purpose it was applied, and was conducted in the statistical population of the employees of Abuzar Hospital in Ahvaz in 2015. All 100 hospital employees were studied. Data collection tool included a researcher-made questionnaire to evaluate in-service educational effectiveness, organizational citizenship behavior questionnaire, job satisfaction questionnaire and organizational commitment questionnaire.

(Hosseini, 2017) in a research investigated "The Effect of Human Resource Management Methods on the Innovation of Service-Oriented Organizations (Case Study: Hafez Hospital, Shiraz)". The purpose of the present research is to investigate the impact of human resource management methods on the innovation of service-oriented organizations. This research was of correlation type. The statistical population of this research includes all managers, deputies and the heads of wards of Hafez Hospital in Shiraz in 2017 that were investigated by census method. 
Data collection tool include a researcher-made questionnaire on human resource management methods and a combination of the organizational innovation questionnaire of (Priyadarshini \& Dave, 2012); (Pfeifer et al., 2013) and (Ford, 2014). To investigate the validity of the questionnaire, face validity and factor analysis methods have been used and to investigate the reliability of the questionnaire, Cronbach's alpha coefficient has been used by applying SPSS-19 software. The results show that the questionnaires of the present research have proper validity and reliability. The results obtained from data analysis performed by inferential correlation statistics and simple regression analysis methods show a positive and significant relationship between human resource management methods (performance evaluation and training and the improvement of human resources) and organizational innovation. Human resource management methods are also able to predict the changes of organizational innovation variable.

(Ghahramani, 2014) in the National Iranian Gas Company has designed and implemented a model of educational excellence in this company through a research project. This research has considered 6 basic values for this model. Also, this model consists of two general sections called enablers and results, that in the enablers section, 5 criteria called leadership and strategy, analysis and need assessment, design and planning, implementation and evaluation, and effectiveness measurement and monitoring the training process are exploited, and in the results section, it introduces 4 criteria called analysis and need assessment results, design and planning results, implementation results, and evaluation and monitoring results.

In a research, (Thomas, 2018) addressed "Education and Development: Investigating the Educational Effectiveness in Employees' Performance". This article talks about the importance of employees in a business, especially when they are properly trained. This article addresses more deeply various educational methods used by various organizations. The pros and cons of training have also been examined. Research findings indicate that training in the organization has a significant effect on employees' performance results, customer satisfaction, turnover ratio, employees' loyalty and market value of the company.

(Sopjani et al., 2017) in a research addressed "Education as an Effective Tool to Increase Knowledge about Organizational Actions: A Study to Evaluate the Educational Effectiveness in Kosovo". The aim of this study was to investigate the effect of World Health Organization (WHO) sanitary multi-purpose company tool in all public hospitals and clinical centers of the University of Kosovo. The research findings indicate that employees' awareness before and after training improved significantly $(\mathrm{p}<0.001)$, and the effect of training on promoting the knowledge of participants had a positive and significant effect. Therefore, the average knowledge promotion was about $41.66 \%$.

(Thabit et al., 2016) in a research addressed "Evaluating the Role of Training Strategy in Increasing Educational Effectiveness". In this article the role of training strategy in increasing educational effectiveness using Performance Leadership Assessment Tool (PLAT) as an instrument to measure the impact of leadership in designing good training programs in the companies was evaluated. The researchers distributed 100 questionnaires randomly in a group of managers, instructors and interns at Al Jazeera companies. The researchers concluded that the design training program should be converted to a precise process of performance evaluation for leaders, instructors and interns, as well as the creation of a specific program for training strategy in each company to create an effective training program.

\section{Materials and Methods}

In general, types of research are classified according to three criteria: a) based on nature b) based on purpose, c) based on the method of data collection. Since the results of the present research can be used for the educational effectiveness for the employees of the selected organization, in terms of nature it can be considered of quantitative research type and in terms 
of purpose, it is considered among applied researches, because the purpose of applied researches is to develop applied knowledge in a specific field. Also, the present research in terms of data collection is among the field of mixed researches, in which interview and questionnaire tools are used. The present research is carried out spatially in the geographical area of Yazd and the statistical population of the research includes all experts and senior managers of the selected organization. According to the research topic, the statistical population of this research consists of all experts and senior managers of the selected organization. The conditions for the interviewees to enter are: 1- Having scientific and executive experiences in the field of employees' empowerment 2- Having compilations in the field of research topic, 3- Having at least five years of work experience in the selected organization.

The sampling method of this research is of judgmental type (non-probable purposeful) due to the limited population. This sampling is used when a limited class of people has the desired information and therefore those are selected as samples that are in the best position to provide the required information. Cochran's formula will be used to estimate the sample size. In this research, in the first stages, a questionnaire is used as a research tool. Questionnaires will be provided to experts during three Delphi stages. It should be mentioned that in the process of performing present research, first by interviewing experts and scholars in the selected organization, a model for research variables has been selected. Since the model used in this research is system dynamics, after extracting the cause-effect model that will be investigated by the experts of the selected organization and after correction, it will be confirmed. The required information will be obtained from interviewing the experts and the library study of available statistics and documents related to the selected organization, and finally the Vensim software outputs will be confirmed by the experts.

\section{System Dynamics}

System dynamics is a method for studying and managing complex systems with feedback. These systems can exist in social fields. This approach was introduced in the early 1960s by Forrester from the University of MIT (Sterman, 2000). This method is the basis for creating computer models in order to perform tasks such as rational analysis of structure, two-way actions and reactions, and behavioral analysis of complex real systems that the human brain is incapable to do. The system dynamics emphasize on the broad behavior of the system and how that behavior will affect the evolution of the system in the future, and thus help ease of decision making. The system dynamics approach is a special type of computer simulation model. This approach is a method of modeling that deals with systems with multiple nonlinear feedback loops, or complex relationships with each other (Langroodi \& Amiri, 2016).

\section{Stages of System Dynamics Model}

Modeling is a feedback process, or in other words, a reaction that is driven by repetition and repetitive cycle. This issue is embedded in the larger cycle of learning and activity that is constantly occurring in organizations. In 2000, Sterman states that, by performing five stages, a system dynamic model is created, that these stages are as follows (Heidari, 2006).

\section{Stage One: Identifying the Problem}

At this stage we need to find the real problem, recognize the key variables and concepts, determine the thinking horizon, and specify the policy of that problem dynamically.

\section{Stage Two: Dynamic Hypotheses}

The modeler must develop and expand a theory of how to stimulate and motivate the problem. This action guides the modeling efforts through specific structures. At this stage we 
need to expand and develop the cause-and-effect loop diagram that explains the causal links between the variables and convert the cause-and-effect diagram into a flow diagram.

\section{Stage Three: Formulating}

To define a system dynamics model, after converting the cause-and-effect loop diagram into a flow diagram, we should convert the system description and explanation to auxiliary level, rate, and equations. We need to estimate some parameters, behavioral relationships, and initial conditions. By writing equations, we clarify the gaps and the lack of inclusions that should be corrected in the initial description and explanation.

\section{Stage Four: Testing}

The purpose of testing is to compare the simulated behavior of the model with the actual behavior of the system.

\section{Stage Five: Formulating and Evaluating the Policy}

When modelers have developed their confidence in the structure and behavior of the model, we can use it to design and evaluate policies for improvement and development. Interactions and mutual effects of various policies should also be considered because real systems are nonlinear (Priyadarshini \& Dave, 2012).

\section{Tools Used in System Dynamics}

In system dynamics, tools are used for modeling which have been introduced below.

\section{Cause-Effect Diagram}

Using a systematic approach, the dynamic system draws the first and the most basic necessary diagram that is "cause-effect diagram". In this diagram, it is tried to draw a dynamic relationship between the factors so that in this way we can better understand the effect of these relationships on the behavior of the system in later stages. Also in this diagram, by determining how the factors affect each other (positive or negative), the feedback of the formed loops is specified, which allows us to control the behavior of the system by applying lever forces.

\section{Inventory Chart - Flow or Rate - Mode}

Inventory-flow or rate-mode diagram is adapted from cause-effect diagrams. In fact, we draw this diagram according to the characteristics of each one of the factors involved and then convert the qualitative relationships determined in the cause-effect diagrams with mathematical equations into quantitative values. By examining the behavior of a variable in a dynamic mode, trends and interactions are predicted (Afshar, 2015).

\section{Behavioral Diagram}

System behavioral diagrams are finally extracted with the help of related software that the analyst by using these diagrams and observing the behavior of the system against changes applied to it analyzes and investigates the behavior of the system and selects the most appropriate strategies for the system (Babaei, 2018). 


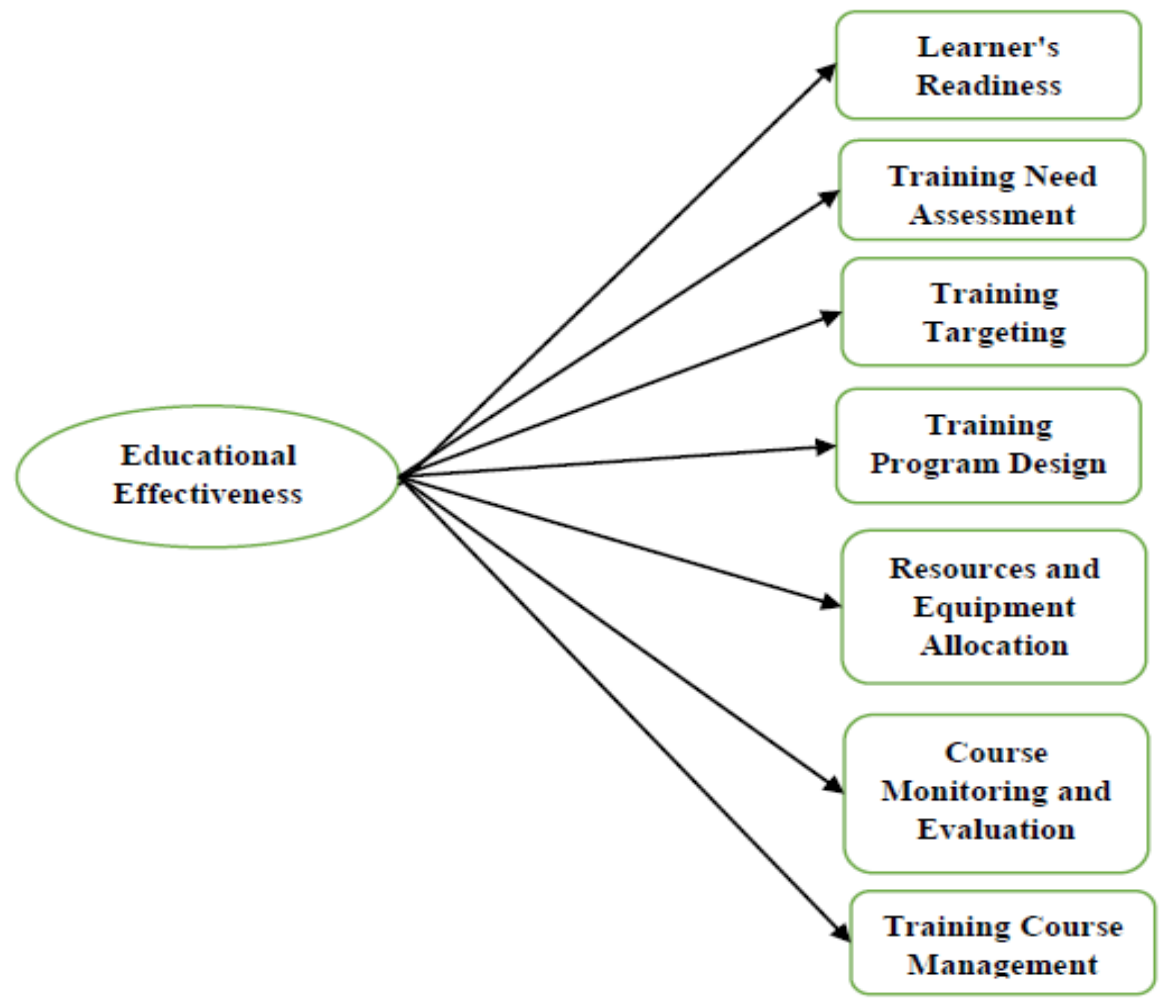

Figure 1. Research Conceptual Model

According to (Figure 1) the provided explanations related to the fit indices, the initial results obtained from the confirmatory factor analysis of the research categories have been presented in the following (Table 1):

\section{Table 1.}

Final Model Fit Indices

\begin{tabular}{|c|c|c|c|}
\hline Index Type & Index & $\begin{array}{l}\text { Acceptable Value for } \\
\text { Model Fit Confirmation }\end{array}$ & Result \\
\hline \multirow[t]{5}{*}{ Absolute } & $\mathrm{X}^{2} / \mathrm{DF}$ & Value between 1 to 3 & Confirmation of the Model Goodness of Fit \\
\hline & RMSEA & Value lower than 0.08 & Confirmation of the Model Goodness of Fit \\
\hline & SRMR & Value lower than 0.08 & Confirmation of the Model Goodness of Fit \\
\hline & GFI & Value higher than 0.9 & Confirmation of the Model Goodness of Fit \\
\hline & AGFI & Value higher than 0.9 & Confirmation of the Model Goodness of Fit \\
\hline \multirow[t]{4}{*}{ Relative } & NFI & Value higher than 0.9 & Confirmation of the Model Goodness of Fit \\
\hline & TLI & Value higher than 0.9 & Confirmation of the Model Goodness of Fit \\
\hline & IFI & Value higher than 0.9 & Confirmation of the Model Goodness of Fit \\
\hline & CFI & Value higher than 0.9 & Confirmation of the Model Goodness of Fit \\
\hline \multirow{3}{*}{ Economic } & PGFI & Value higher than 0.5 & Confirmation of the Model Goodness of Fit \\
\hline & PNFI & Value higher than 0.5 & Confirmation of the Model Goodness of Fit \\
\hline & PCFI & Value higher than 0.5 & Confirmation of the Model Goodness of Fit \\
\hline
\end{tabular}

(Research Findings) 


\section{Results}

\section{Research Findings}

As it is specified from the (Table 1), almost all fit indicators of confirmatory factor analysis indicate the model goodness of fit.

Based on the review of theoretical foundations and research history in the field of system dynamics, indicators and criteria were enumerated, which have been presented in the (Table 2).

\section{Table 2.}

Extracted Indicators of System Dynamics

\begin{tabular}{|c|c|c|c|c|c|c|}
\hline Title & $\begin{array}{l}\text { Effective Eval- } \\
\text { uation with } \\
\text { Dynamic } \\
\text { Changes over } \\
\text { Time }\end{array}$ & $\begin{array}{c}\text { Feedback } \\
\text { Process } \\
\text { Analysis }\end{array}$ & $\begin{array}{l}\text { Ability to Use } \\
\text { Soft Data }\end{array}$ & $\begin{array}{c}\text { Facilitating } \\
\text { Alternative } \\
\text { Strategies Test- } \\
\text { ing }\end{array}$ & $\begin{array}{l}\text { Explanation and } \\
\text { Troubleshooting }\end{array}$ & $\begin{array}{c}\text { Process } \\
\text { Evaluation }\end{array}$ \\
\hline $\begin{array}{l}\text { (Evans et } \\
\text { al. 2001) }\end{array}$ & & $\checkmark$ & & & $\checkmark$ & \\
\hline $\begin{array}{l}\text { (Barlas, } \\
\text { 2002) }\end{array}$ & $\checkmark$ & & & & & $\checkmark$ \\
\hline $\begin{array}{l}\text { (Shin et al., } \\
\text { 2014) }\end{array}$ & & & $\checkmark$ & $\checkmark$ & & \\
\hline $\begin{array}{l}\text { (Lee et al., } \\
2015)\end{array}$ & $\checkmark$ & & & $\checkmark$ & & $\checkmark$ \\
\hline $\begin{array}{l}\text { (Liu et al., } \\
\text { 2007) }\end{array}$ & & $\checkmark$ & $\checkmark$ & & $\checkmark$ & \\
\hline $\begin{array}{l}\text { (Bloodgood } \\
\text { et al., 2015) }\end{array}$ & $\checkmark$ & & & $\checkmark$ & & $\checkmark$ \\
\hline $\begin{array}{l}\text { (Destyanto } \\
\text { et al., 2017) }\end{array}$ & & $\checkmark$ & & & $\checkmark$ & \\
\hline
\end{tabular}

(Research Findings)

Based on the (Table 2), it was specified that the indicators of system dynamics are effective evaluation with dynamic changes over time, feedback process analysis, the capability to use soft data, facilitating alternative strategies testing, process explanation and troubleshooting and evaluation.

Cause-effect diagram in this research was obtained based on performed interviews. With the fuzzy Delphi approach, these factors were finalized. Then articles about the relationship between these indicators were analyzed and the relationships between these factors and dimensions were extracted and by putting these relationships together, cause-effect loops were formed one by one. By putting these loops together, cause-effect diagram was formed. This initial diagram during several stages was examined by experts' opinion and new relationships were established between the variables. Following this work, the final model of educational effectiveness of the employees of the selected organization was investigated and confirmed.

(Figure 2) shows the cause-effect diagram of this research, which some points will be stated about some of its loops in the following. 


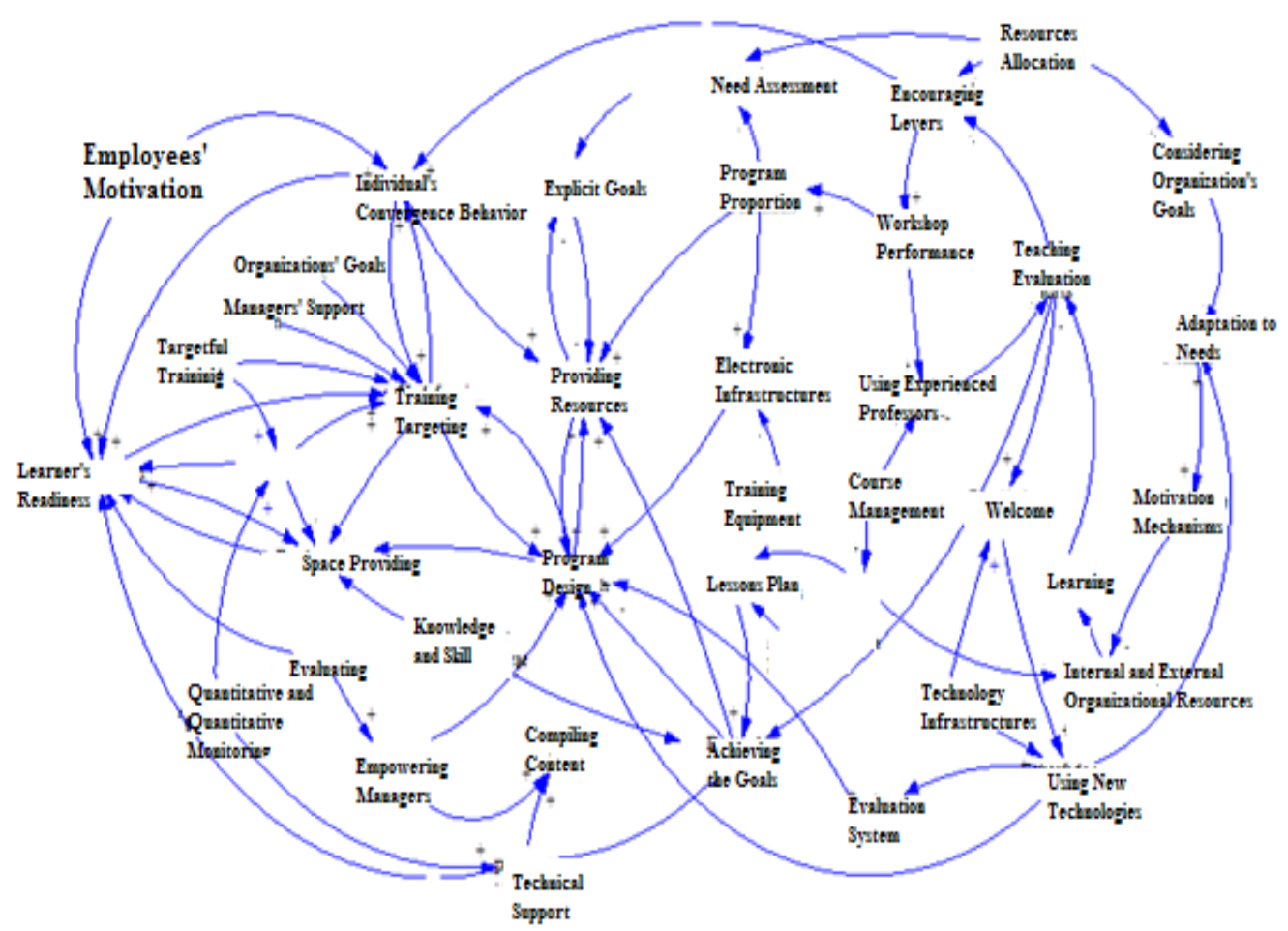

Figure 2. Cause-Effect Diagram

(Figure 3) shows one of the modulating loops of the cause-effect diagram of the problem. One of the advantages of allocating resources is to help creating a suitable environment for education and using experienced professors.

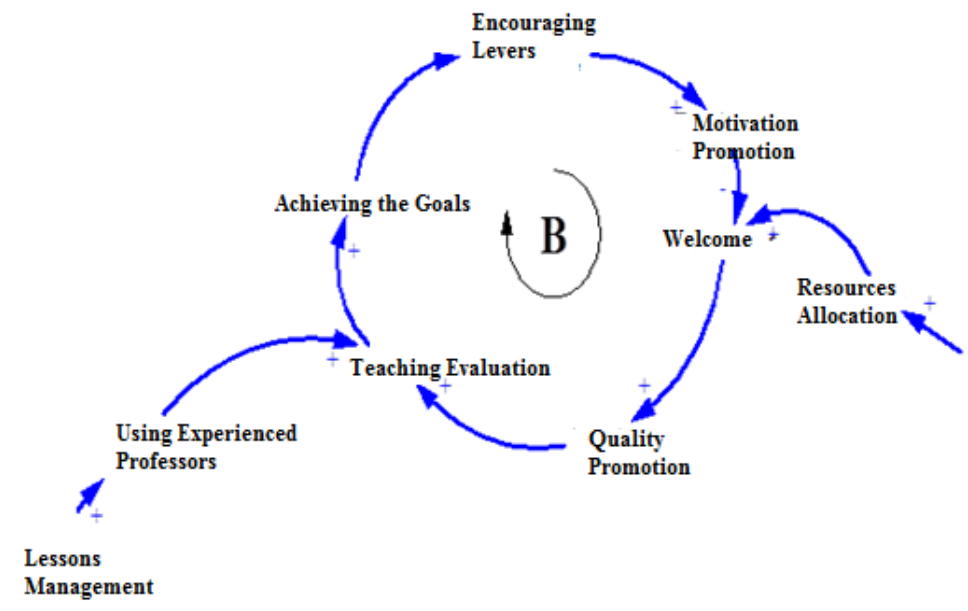

Figure 3. Cause-Effect Diagram Loop of the Effect of Course Management on the Educational Effectiveness

(Figure 4) is one of the reinforcing loops of the problem model. As it has been shown in the figure, the managerial activities of the organization are effective in improving the quality of education. 


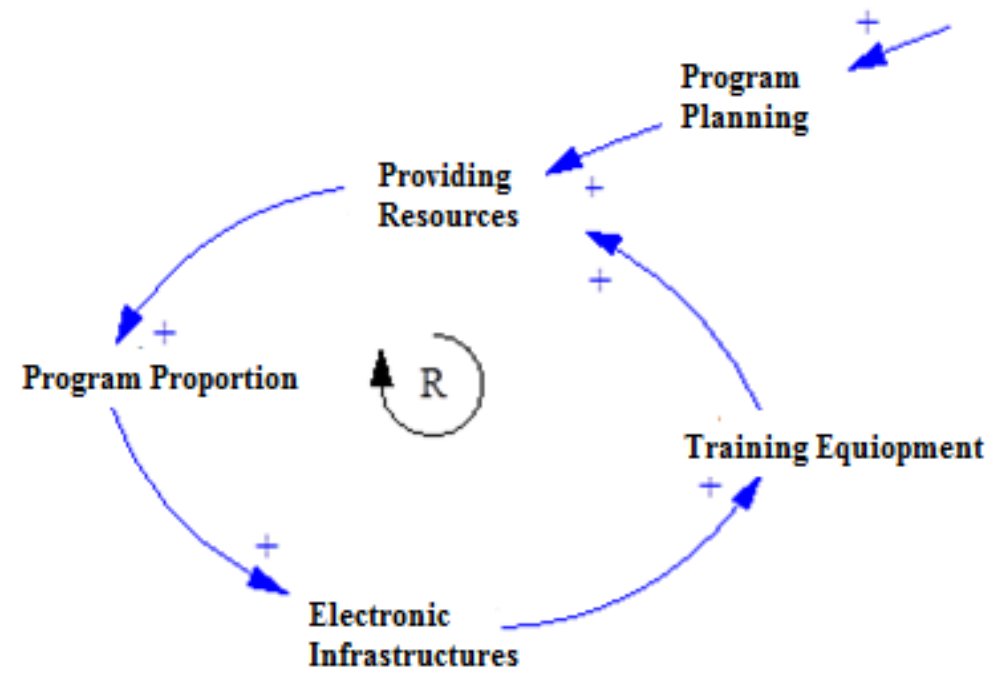

Figure 4. Cause-Effect Loop of the Effect of Program Design on the Educational Effectiveness

The following loop is one of the modulating loops of cause-effect diagram of the model of this research. The design of the program affect to some extent the provision of resources and equipment; by this process the provision of resources and equipment and the educational effectiveness will also increase (Figure 5).

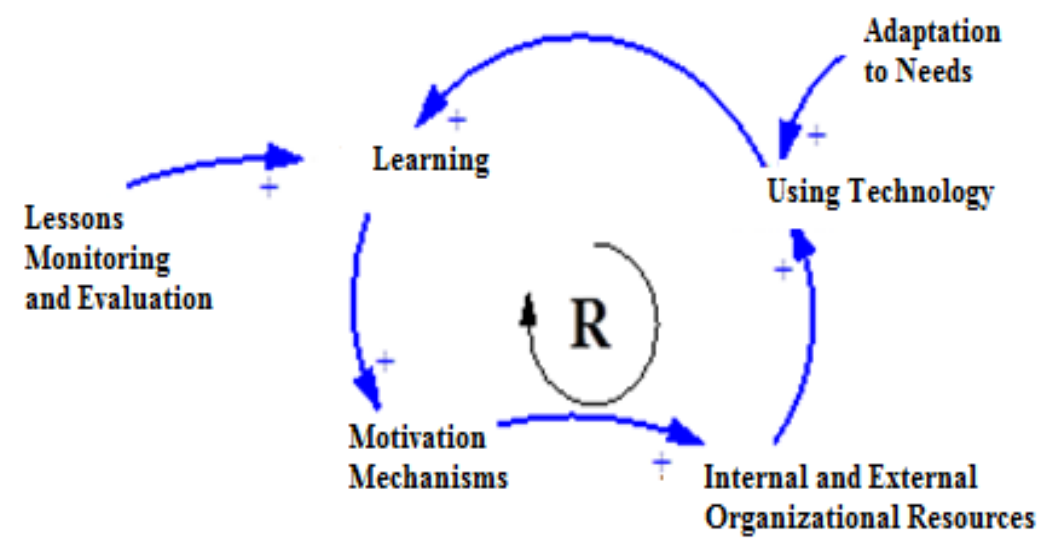

Figure 5. Cause-Effect Diagram Loop of the Effect of Course Monitoring and Evaluation on the Educational Effectiveness

(Figure 6) shows another example of a problem reinforce loop. Course monitoring and evaluation will have a positive effect on the educational effectiveness; this change will not be ineffective on learning either, and will increase the educational effectiveness. 


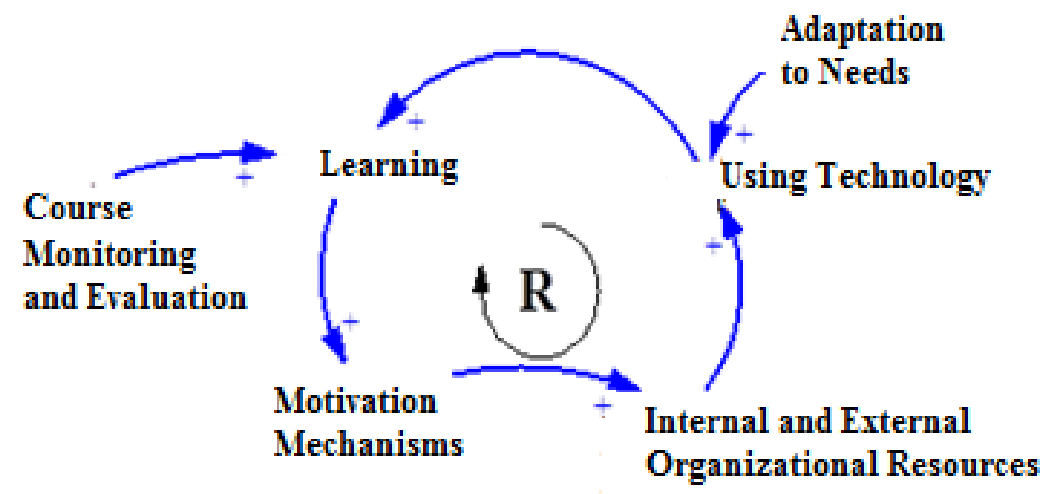

Figure 6. Cause-Effect Diagram Loop of the Effect of Course Monitoring and Evaluation on the Educational Effectiveness

\section{Research Final Model Fitness}

In the following, the results of path analysis of the educational effectiveness model of the employees of the selected organization have been presented (Figure 7).

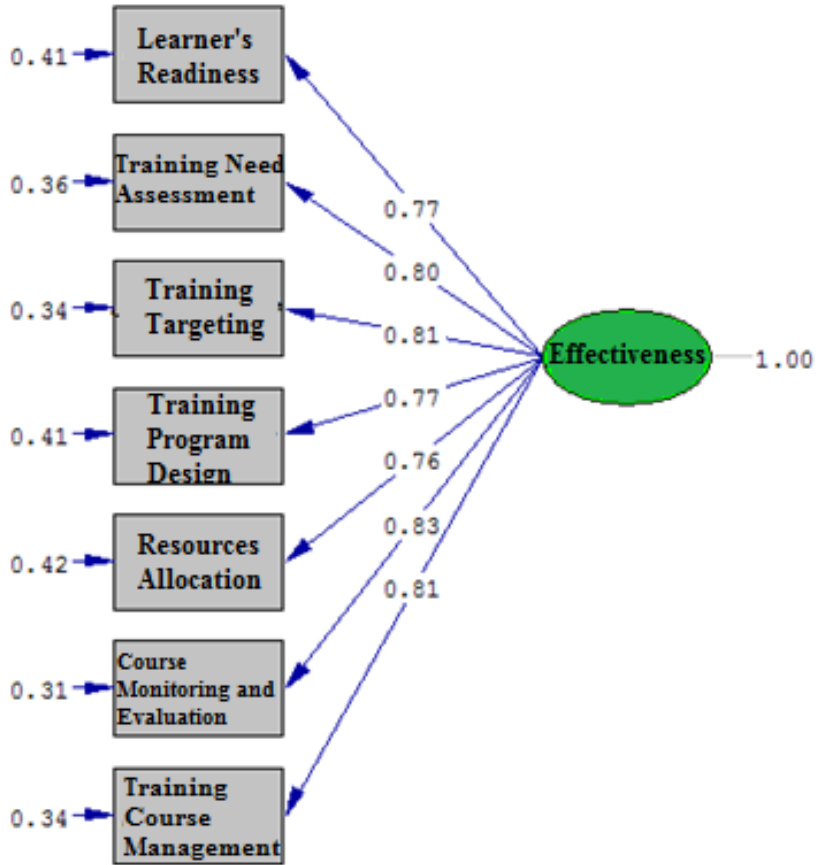

Chi-Square=1043.24, $\mathrm{df}=346, \mathrm{P}-\mathrm{value}=0.00000, \mathrm{RMSEA}=0.063$

Figure 7. Educational Effectiveness Model of the Employees of the Selected Organization in the Standard Coefficients State 


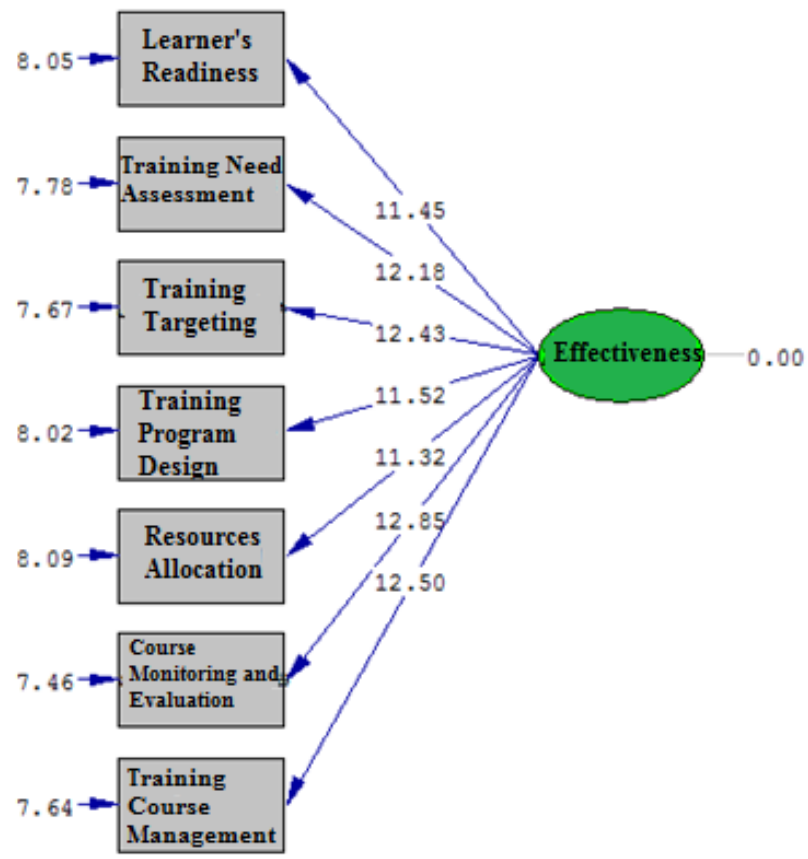

Chi-Square=1043.24, $\mathrm{df}=346, \mathrm{P}-\mathrm{value}=0.00000, \mathrm{RMSEA}=0.063$

Figure 8. Educational Effectiveness Model of the Employees of the Selected Organization in the t Significance Numbers State

As it is observed in (Figure 8), all significance numbers related to the model parameters (including factor loads and their errors) have become significant, because their significance number is higher than 1.96. In the following and in the (Table 3), the fitness indicators of the educational effectiveness model of the employees of the selected organization have been reported.

\section{Table 3.}

General Fit Indicators of the Educational Effectiveness Model of the Employees of the Selected Organization

\begin{tabular}{lc}
\hline Index & Estimate \\
\hline Chi-Square Ratio to Degree of Freedom $\left(\chi^{2} / \mathrm{df}\right)$ & 3.01 \\
\hline Root Mean Square Error of Approximation (RMSEA) & 0.063 \\
\hline Goodness of Fit Index (GFI) & 0.93 \\
\hline Adjusted Goodness of Fit Index (AGFI) & 0.91 \\
\hline Comparative Goodness of Fit Index (CFI) & 0.93 \\
\hline Normed Fit Index (NFI) & 0.92 \\
\hline
\end{tabular}

According to the results of the (Table 3), the structural model fit indices show that the model has a relatively good fit; although the Chi-square index on the degree of freedom is slightly higher than 3 , the root mean square error of approximation is lower than 0.08 and other indices have been obtained higher than 0.90 .

\section{Discussion}

The research results showed that the model of educational effectiveness of the employees of the selected organization with a system dynamics approach has two parts: the main factors and their indicators. This model has been composed of indicators that are the core and heart of this model 
and are the basis for evaluating the educational effectiveness, which are called effective factors. The model of educational effectiveness of the employees of selected organization with a system dynamics approach has 7 main factors: learner's readiness, training need assessment, training targeting, training program design, resources and equipment allocation, course monitoring and evaluation and training course management, which includes 56 indicators composing them. For the development and expansion of each one of the factors they are supported by a number of indicators. Indicators in fact explain the meaning and concept of each factor that should be considered during the evaluation of the educational effectiveness of the employees of the selected organization with a system dynamics approach. Findings of the research about the model of the educational effectiveness of the employees of the selected organization are consistent with the results of (Babaei, 2018), (Ali Poorian, 2015), (Thomas, 2018), (Heidari, 2013) and (AlYahya, 2013). Findings of the research in the field of the model of educational effectiveness of the employees of the selected organization are consistent with the results of (Arab Shiraz, 2011). Arab Shiraz in his research has evaluated the in-service training courses effectiveness of the employees of the Petroleum Products and Distribution Company headquarter and has concluded that in terms of individual factors, the research results indicated that according to the statements of the respondents, the most important factor regarding the effect of the level of individual characteristics in promoting the training courses effectiveness has been the trainee's talent for active presence in the course, and afterwards the motivation of transfer, self-efficacy and learner's readiness, respectively. In relation to environmental (organizational) factors, the most important factor regarding the effect of environmental characteristics in promoting the training courses effectiveness are the support of colleagues for active presence in the course, and afterwards supervisors' support, performance expected from trying to transfer, positive individual results, the opportunity to use, negative personal results, the supervisor's permission and freedom respectively. Research findings of (Mohammad Hosseini Lalani, 2015) also showed that the component of motivational elements is in the first rank, secondary factors are in the second rank, elements of ability are in the third rank and environmental factors are in the fourth rank.

\section{Conclusion}

The quality of in-service training teachers, the quality of in-service training courses facilities and equipment, holding in-service training courses in the form of distance education, the implementation of in-service training courses consecutively, and the quality of learners in inservice training courses had a positive and significant relationship with performance, which is consistent with the results of the research. According to the research findings and the confirmation of learner's readiness as one of the elements of the educational effectiveness model, it is suggested that the inclusive motivation to participate in courses in order to acquire skill be promoted and financial and non-financial incentive mechanisms be considered for active presence of employees. According to the research findings and the confirmation of training need assessment as one of the elements of the educational effectiveness model, it is suggested that courses be designed according to the needs and realities of the organization and training and learning are compatible with job training needs and duplicate trainings are avoided. According to the research findings and the confirmation of training targeting as one of the elements of the educational effectiveness model, it is suggested that training courses be in line with organizational goals and the objectives of training courses for employees should be clearly stated and the organizational goals based on the type of defined services should be considered in accordance with the rules and regulations. The limitations of this research include the following cases: The statistical population of the research has been limited only to the employees of the selected organization, the categories obtained in the qualitative part of the research is taken from the experts and senior managers of the selected organization and their perception of the subject, while if another person has examined the interviews, other categories and subcategories might be obtained. In the research process, disturbing and intervening variables may have affected the research results that were not controlled. 


\section{References}

Salas j. (2013), BUSINESS Dynamics: Systems Thinking and Modelling for a Complex World, New York: McGraw-Hill, 3(6): 125-134.

Priyadarshini R. \& Dave D. (2012), Competency-based Training Needs Assessment Model. Management and Labour Studies, 37(3): 195-207.

Pfeifer C. \& Janssen S. \& Yang P. \& Backes-Gellner U. (2013), Effects of training on employee suggestions and promotions: Evidence from personnel records.Schmalenbach Business Review (SBR), 65(3): 270-287.

Ford J. (2014), Improving training effectiveness in work organizations. Psychology Press, 19(4): 316-330.

Snell G. \& Bohlander S. (2010), Managing Human Resource/ $14^{\text {th }}$ edition, printed in United State of America, 9(2): 308-319.

Khorasani A. \& Hasanzadeh Rain S. (2007), Strategies and Strategies for Educational Needs Assessment, Tehran, Iran Center for Education and Research, 11(2): 23-45.

Seyed Javadin S. (2008), The Basics and Applications of Human Resources Management and Staff Affairs, Tehran, Publishing House of Science, 12(2): 2-5.

Ghahremani M. (2008), Evaluating the Effectiveness of Project Master's Courses and Operations and Operations Management, Management and Development Quarterly, 11(3): 2356.

Nasreen A. \& Mirza M. (2012), Faculty Training and Development in the Public Sector Universities of Punjab. International Journal of Business and Social Science, 3(3): 229-238.

Sterman j. (2000), BUSINESS Dynamics: Systems Thinking and Modelling for a Complex World, New York: McGraw-Hill, 12 (7): 110-119.

Langroodi R. \& Amiri M. (2016), A system dynamics modeling approach for a multi-level, multi-product, multi-region supply chain under demand uncertainty. Expert Systems with Applications; 51(2): 231-244.

Heidari H. (2006), Pathology of in-service training of Shahid Beheshti University staffs based on Halton model presented at second training conference in Tehran: Afagh Industrial Co., Bahman Moon, 3(3): 45-47.

Afshar A. (2015), The Effect of In-Service Education on the Effectiveness of the Employees of the SADERAT Bank (Center of Tehran), Islamic Azad University, Central Tehran Branch, Faculty of Management and Accounting, 3(3): 45-47.

Babaei L. (2018), Evaluation of the Effectiveness of Entrepreneurship Education Courses in Mohammad Khani Conservatory on Girls' Affairs in Shahroud, Shahrood Islamic Azad University, School of Management and Accounting, 19(4): 89-99.

Bani Davoudi S. \& Atabi M. (2018), The Relationship Between Employee Service Periods and Occupational Outcomes in Aboozar Hospital in Ahvaz, Journal of Paramedical Sciences, Tehran University of Medical Sciences, 11(1): 94-103.

Hosseini F. (2017), The Effect of Human Resources Management on the Innovation of ServiceOriented Organizations (Case Study: Hafez Hospital of Shiraz), Islamic Azad University, Marvdasht Branch, Faculty of Educational Sciences and Psychology, 5(4): 30-39.

Ghahramani M. (2014), Evaluation of the Effectiveness of Master's Courses in Project and Operations and Operations Management, Management and Development Quarterly, 11(4): $10-14$.

Thomas O. (2018), Training and Development, Exploring the Effectiveness of Training on Worker Performance, 8(2): 58-64.

Sopjani I. \& Jahn P. \& Behrens J. (2017), Training as an effective tool to increase the knowledge about hand hygiene actions. An evaluation study of training effectiveness in Kosovo. Medical Archives, 71(1): 160-175.

Thabit H. \& Aissa S. \& Abdullah H. (2016), Evaluating the Role of Training Strategy in Enhancing the Training Effectiveness. les cahiers du mecas, 12(2): 4-18. 
Evans T. \& Manire A. \& de Castro F. \& Brondizio E. \& McCrachen S. (2001), A dynamic model of household decision-making and parcel level landcover change in the eastern Amazon. Ecol, Model, 14(3): 95-113.

Barlas Y. (2002), System dynamics: systemic feedback modeling for policy analysis in knowledge for sustainable development-an insight into the encyclopedia of life support systems. Paris, France, Oxford, UK: UNESCO Publishing-Eolss Publishers, 6(2): 4157.

Shin M. \& Lee H. \& Park M. \& Moon M. \& Han S. (2014), A system dynamics approach for modeling construction workers' safety attitudes and behaviors, Accident Analysis \& Prevention, 11(8): 178-190.

Lee S. \& Han W. \& Park Y. (2015), Measuring the functional dynamics of product-service system: A system dynamics approach. Computers \& Industrial Engineering, 6(4): 159-170.

Liu M. \& Anita Chiu W. \& Fellows R. (2007), Enhancing commitment through work empowerment, Engineering, Construction and Architectural Management, 14(6): 568-580 .

Bloodgood J. \& Hornsby J. \& Burkemper A. \& Sarooghi H. (2015), A system dynamics perspective of corporate entrepreneurship. Small business economics, 45(2): 383-402.

Destyanto A. \& Moeis A. \& Hidayatno A. \& Iman R. (2017), System Dynamics Approach for Managing Turnover Problem in Professional Service Firm, 9(5): 96-107.

Ali Poorian A. (2015), Evaluation of the effectiveness of the performance of in-service training courses from the perspective of staff members of the cultural and artistic centers of mosques in Tehran province, Islamic Azad University, Central Tehran Branch, Faculty of Education and Psychology, 4(3): 47-55.

AlYahya M. (2013), Evaluation of training effectiveness of training and development, Asian Journal of Business and Management Sciences, 2(11): 14-24.

Arab Shiraz N. (2011), Evaluation of the Effectiveness of In-Service Training Courses of the National Iranian Broadcasting Company and its Oil Products Based on the Halton Transfer Transfer Model, Master's thesis, Faculty of Educational Sciences and Psychology, Tehran University, 13(6): 122-131.

Heidari H. (2013), Evaluation of the Effectiveness of In-Service Training Courses of the Employees of the Bank of Rafah Based on the Halton Transfer Model. Thesis for Master's Degree in Educational Management, Faculty of Educational Sciences and Psychology, Shahid Beheshti University of Tehran, 17(5): 140-153.

Mohammad Hosseini Lalani S. (2015), The Effectiveness of In-Service Education on the Performance of Primary School Teachers in Pakdasht, Islamic Azad University, Central Tehran Branch, Faculty of Educational Sciences and Psychology, 16(5): 170-184. 